\title{
Application of cesium hydroxide monohydrate for ring opening polymerization of monosubstituted oxiranes: characterization of synthesized polyether-diols
}

\section{Zbigniew Grobelny $^{1}$ (D) Justyna Jurek-Suliga ${ }^{2} \cdot$ Sylwia Golba $^{2}$}

Received: 12 December 2018 / Revised: 29 October 2020 / Accepted: 6 November 2020 /

Published online: 19 November 2020

(C) The Author(s) 2020

\begin{abstract}
Cesium hydroxide monohydrate $\left(\mathrm{CsOH} \cdot \mathrm{H}_{2} \mathrm{O}\right)$ activated by cation complexing agents, i.e., $18 \mathrm{C} 6$ or $\mathrm{C} 222$ was applied as initiator of monosubstituted oxiranes polymerization. Propylene oxide (PO), 1,2-butylene oxide (BO), styrene oxide (SO) and some glycidyl ethers were used as monomers. All processes were carried out in tetrahydrofuran solution at room temperature. Such polymers, as PPO-diols, PBO-diols and PSO-diols, are unimodal and have molar masses $M_{\mathrm{n}}=2000-5100$. Their dispersities are rather high $\left(M_{\mathrm{w}} / M_{\mathrm{n}}=1.17-1.33\right)$. Moreover, PPO-diols and PSO-diols are not contaminated by monools with unsaturated starting groups. Poly(glycidyl ether)s are, in general, polymodal. For example, poly(isopropyl glycidyl ether)-diols are bi- or trimodal, whereas poly(allyl glycidyl ether)-diols possess two or even six fractions. Molar masses of main fraction are 4200-6400, and the second fraction is much lower, namely 600-2600. Dispersities of some fractions are very low $\left(M_{\mathrm{w}} / M_{\mathrm{n}}=1.01-1.07\right)$. Polymodality of polymers obtained was discussed in terms of the formation of two or more species propagating with different rate constants.
\end{abstract}

\section{Graphic abstract}

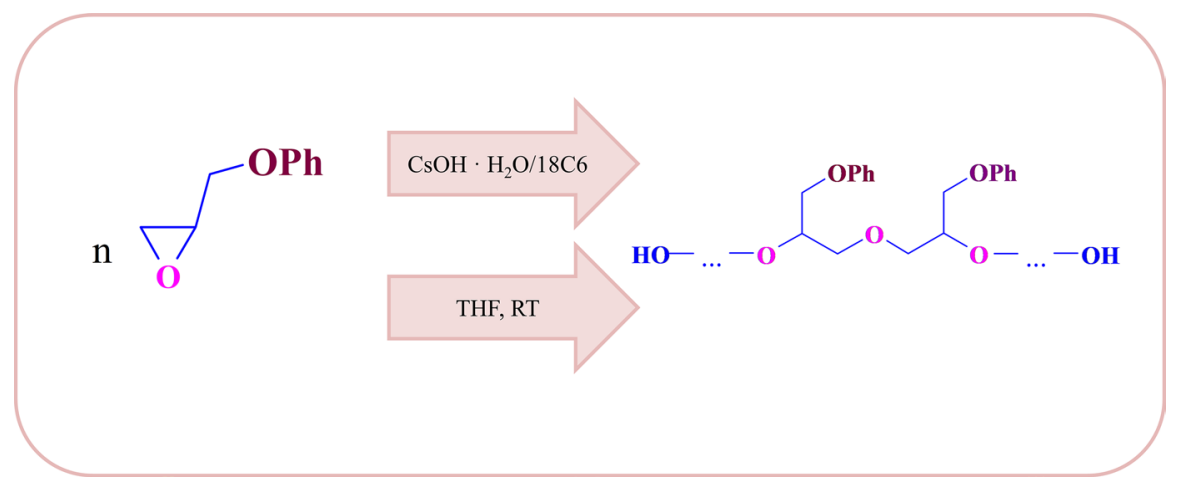

Extended author information available on the last page of the article 
Keywords Cesium hydroxide monohydrate $\cdot$ Ring opening polymerization

Monosubstituted oxiranes $\cdot$ Polyether-diol

\section{Introduction}

Polyethers are an important class of synthetic polymers, which have many applications, e.g., as impact modifiers, surfactants, de-emulsifiers, dispersant agents, fuel additives, lubricants, biomedical materials or adhesives [1-5]. Especially interesting are polyether- and copolyether-diols or triols prepared from oxiranes, i.e., ethylene oxide (EO), propylene oxide (PO) or 1,2-butylene oxide (BO), which are applied for fabrication of polyurethane elastomers or foams [6]. Many initiators were used for anionic ring-opening polymerization of oxiranes, e.g., potassium hydroxide [7, 8] or potassium alkoxides [9-15]. In industry, the most frequently used are $\mathrm{KOH} / 1,2-$ propylene glycol or glycerol systems, which allow to obtain PPO-diols or PPO-triols with $M_{\mathrm{n}}=2000-6000$ at $110^{\circ} \mathrm{C}[6,16]$. The polymers possess low unsaturation due to excess of hydroxylic compound used, which strongly limited chain transfer reaction to monomer. On the other hand, PPOs with $M_{\mathrm{n}}=9000$ and high unsaturation were prepared in the polymerization initiated with anhydrous $\mathrm{KOH}$ in THF solution at room temperature [8]. It was proposed, that in this case deprotonation of the monomer by initiator and active centers of growing chains occur to a wide extend. $\mathrm{KOH}$, $\mathrm{RbOH}$ and $\mathrm{CsOH}$ are effective catalysts, while $\mathrm{LiOH}$ and $\mathrm{Na} \mathrm{OH}$ are ineffective $[17,18]$. Unsaturation of PPOs depends strongly on the nature of alkoxide cation. The relative order of alkoxide reactivity in the transfer reaction with the monomer is: $\mathrm{Li}^{+}>\mathrm{Na}^{+}>\mathrm{K}^{+}>\mathrm{Rb}^{+}>\mathrm{Cs}^{+}[19,20]$. This effect is rather unexpected and needs some comments. Basicity of hydroxides and alkoxides increases from $\mathrm{Li}^{+}$to $\mathrm{Cs}^{+}$ [21]. Deprotonation of PO occurs in the complex involving monomer and active ion pair of growing chain $[6,10]$ (Scheme 1).

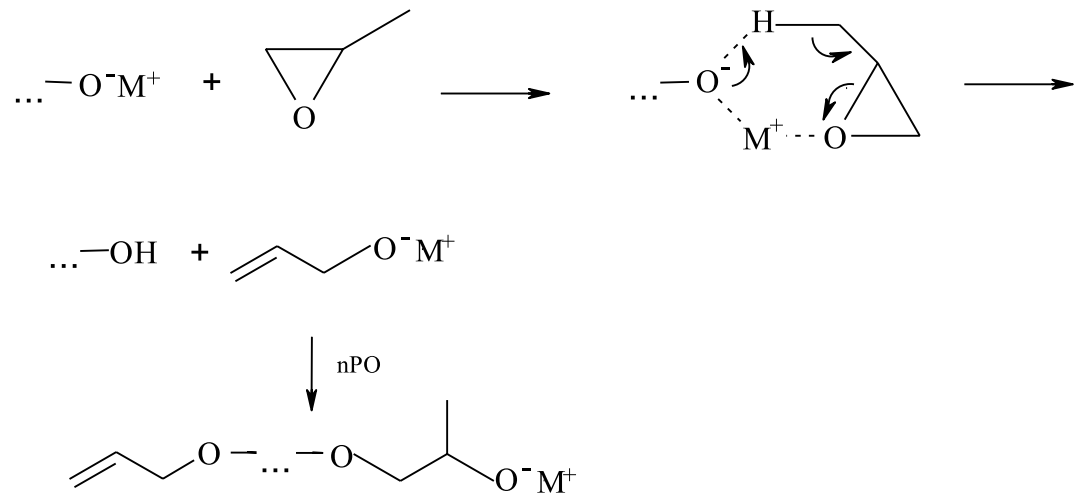

where $\mathrm{M}^{+}$denotes alkali metal cation

Scheme 1 Deprotonation of PO by E2 elimination during anionic polymerization (side reaction of chain transfer to monomer) 
In our opinion, decreasing of deprotonation observed from $\mathrm{Li}^{+}$to $\mathrm{Cs}^{+}$could be explained by increasing of ionic radii of the metal cation (from $60 \mathrm{pm} \mathrm{for} \mathrm{Li}^{+}$to $169 \mathrm{pm}$ for $\mathrm{Cs}^{+}$), which causes an increase in steric hindrance. On the other hand, in the polymerization initiated with potassium alkoxides and other salts activated coronand 18-crown-6 (18C6), formation of big $\mathrm{K}^{+} 18 \mathrm{C} 6$ complexes results in direct deprotonation of the monomer and high unsaturation [15] (Scheme 2).

It was also worth noting that PPOs synthesized in the presence of $\mathrm{KOH} /$ $\mathrm{H}_{2} \mathrm{O} / 18 \mathrm{C} 6$ [8] or $t$-BuOK/t-BuOH/18C6 [14] systems have very low unsaturation and $M_{\mathrm{n}}$ due to chain transfer reaction to hydroxylic compound.

The aim of the present work was characterization of polyether-diols prepared by ring opening polymerization of several monosubstituted oxiranes initiated with cesium hydroxide monohydrate $\left(\mathrm{CsOH} \cdot \mathrm{H}_{2} \mathrm{O}\right)$. This reagent was useful for synthesis of dicesium 1,2-propanedioxide, which was applied for some oxiranes copolymerization [22]. However, till now, it has not been used for initiation of oxiranes polymerization. Propylene oxide, 1,2-butylene oxide, styrene oxide, isopropyl glycidyl ether, allyl glycidyl ether and phenyl glycidyl ether were chosen as monomers for the study. Polymerizations were carried out in THF solution at room temperature. The influence of initial monomer concentration and kind of ligand complexing counterion (L), i.e., coronand 18C6 or cryptand C222 on molar mass $\left(M_{\mathrm{n}}\right)$, dispersity $\left(M_{\mathrm{w}} / M_{\mathrm{n}}\right)$ and modality of the prepared polymers were studied and discussed. ${ }^{13} \mathrm{C}$ NMR, MALDI-TOF and SEC techniques were used for analysis of polymers.

\section{Experimental}

\section{Materials}

Monomers, i.e., propylene oxide, 1,2-butylene oxide, styrene oxide, isopropyl glycidyl ether, allyl glycidyl ether and phenyl glycidyl ether (from Aldrich) were dried over $\mathrm{CaH}_{2}$ and distilled at $307 \mathrm{~K}\left(34^{\circ} \mathrm{C}\right), 336 \mathrm{~K}\left(63{ }^{\circ} \mathrm{C}\right), 467 \mathrm{~K}\left(194{ }^{\circ} \mathrm{C}\right)$, $414 \mathrm{~K}\left(131^{\circ} \mathrm{C}\right), 427 \mathrm{~K}\left(154^{\circ} \mathrm{C}\right)$ and $518 \mathrm{~K}\left(245^{\circ} \mathrm{C}\right)$, respectively. Anhydrous tetrahydrofuran (THF) (Acros Organics) was kept over $\mathrm{CaH}_{2}$ and distilled at $339 \mathrm{~K}\left(66^{\circ} \mathrm{C}\right)$. Coronand $18 \mathrm{C} 6$ (Merck), cryptand $\mathrm{C} 222$ (Merck) and $\mathrm{CsOH} \cdot \mathrm{H}_{2} \mathrm{O}$ (Aldrich) were used without purification.

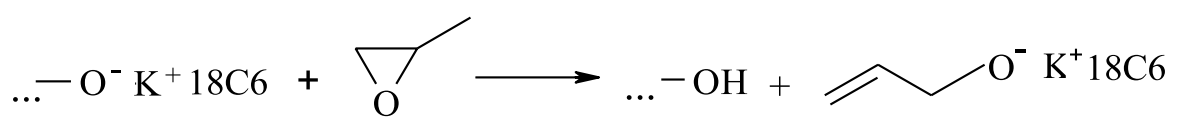

Scheme 2 Direct deprotonation of PO 


\section{Synthesis}

All syntheses were carried out at $20{ }^{\circ} \mathrm{C}$ in a $50 \mathrm{~cm}^{3}$ reactor equipped with a magnetic stirrer and a Teflon valve enabling substrates delivery and sampling under argon atmosphere. In the first series of polymerizations of propylene oxide, the initial concentration of the monomer was equal to $2.0 \mathrm{~mol} / \mathrm{dm}^{3}$ and the initial amount of $\mathrm{CsOH} \cdot \mathrm{H}_{2} \mathrm{O}$ $(0.34 \mathrm{~g}, 2.0 \mathrm{mmol})$ and THF $\left(17.0 \mathrm{~cm}^{3}\right)$ was introduced into reactor and then $18 \mathrm{C} 6$ $(0.53 \mathrm{~g}, 2.0 \mathrm{mmol})$ was added. The mixture was stirred during $30 \mathrm{~min}$. That system was used as the initiator, when the monomer $\left(2.8 \mathrm{~cm}^{3}, 2.4 \mathrm{~g}, 40.0 \mathrm{mmol}\right)$ was introduced into the reactor. The reaction mixture was then stirred during $170 \mathrm{~h}$. After this time complete conversion of the monomer occurred and the reaction mixture was neutralized with $\mathrm{HCl} / \mathrm{H}_{2} \mathrm{O}$ system $\left(0.1 \mathrm{~mol} / \mathrm{dm}^{3}, 50 \mathrm{~cm}^{3}\right)$ and transferred to the separator containing chloroform $\left(70 \mathrm{~cm}^{3}\right)$. After shaking during $5 \mathrm{~min}$, two layers were obtained, i.e., interferior polyether layer and superior layer containing water and the cesium salt. There layers were separated, and the superior layer was removed. After three washings with distilled water, polyether was obtained by evaporating of chloroform and water in vacuum at elevated temperature. In the next series, polymerizations were performed in the presence of other ligand C222 and higher initial concentration of the monomer, i.e., $5.0 \mathrm{~mol} / \mathrm{dm}^{3}$. Similar procedure was applied for polymerization of other oxiranes. The concentration of monomer during the polymerizations was monitored by the 1,4-dioxane method [23]. The final conversions were $99 \%$. The yields of the reactions were 97-99\%. All studied processes were heterogeneous and part of initiator remained at the end polymerization.

\section{Measurements}

$100 \mathrm{MHz}{ }^{13} \mathrm{C}$ NMR spectra were recorded in $\mathrm{CDCl}_{3}$ at $25{ }^{\circ} \mathrm{C}$ on a Bruker Avance 400 pulsed spectrometer equipped with $5 \mathrm{~mm}$ broad-band probe and applying Waltz16 decoupling sequence. Chemical shifts were referenced to tetramethylsilane serving as an internal standard. To obtain a good spectrum of the polymer main chain exhibiting its microstructural details, about 3000 scans were sufficient but in order to observe the signals of the polymer chain terminal groups more than 10,000 scans were necessary. Molar masses and dispersities of polymers were obtained by means of size exclusion chromatography (SEC) on a Shimadzu Prominance UFLC instrument at $40{ }^{\circ} \mathrm{C}$ on a Shodex $300 \mathrm{~mm} \times 8 \mathrm{~mm}$ OHpac column using THF as a solvent. Polstyrenes were used as calibration standards. MALDI-TOF spectra were recorded on a Shimadzu AXIMA Performance instrument. Dithranol was used as a matrix.

\section{Results and discussion}

It was observed, that $\mathrm{CsOH} \cdot \mathrm{H}_{2} \mathrm{O}$ is practically insoluble in $\mathrm{THF}$ at room temperature and does not initiate polymerization of oxiranes. Therefore, all processes were carried out with this initiator, which is activated by macrocyclic ligands complexing 
<smiles>C1CCOCCOCCOCCOCCOCCOC1</smiles>

coronand $18 \mathrm{C} 6$

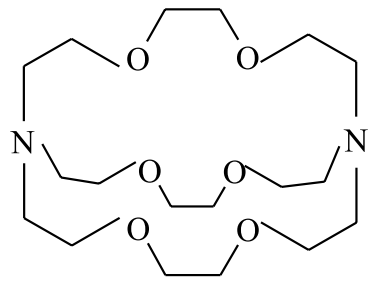

cryptand C222

Scheme 3 Ligands (L) for metal cations

$$
\mathrm{CsOH} \cdot \mathrm{H}_{2} \mathrm{O}+\mathrm{L} \rightleftharpoons \mathrm{Cs}^{+} \mathrm{LOH}^{-}+\mathrm{H}_{2} \mathrm{O}
$$

Scheme 4 Equilibrium involving complexation of initiator by ligand

metal cations, i.e., $18 \mathrm{C} 6$ or C222 (Scheme 3). It allowed to increase the reactions rate and yield of the polymers.

Both ligands cause ionization of initiator, which results in the formation of ligand separated ion pairs existing in equilibrium with solid salt. Thus, the concentration and reactivity of initiator increase markedly in the presence of ligand and initiator of the polymerization occurs in the solution (Scheme 4).

Due to the ratio of the ionic cesium cation radius to the $18 \mathrm{C} 6$ cavity radius $\approx 1.2$ [24], it is theoretically possible to exist in equilibrium two kinds of complexes, i.e., flat (1/1) and sandwich (1/2) ones [25]. Cryptand C222 is able to form exclusive and inclusive complexes being in equilibrium, but in THF the formation of the inclusive complex was hindered by the strong cation-anion interaction [26].

Table 1 Characterization of PPO-diols, PBO-diols and PSO-diols obtained in the polymerization of oxiranes initiated with $\mathrm{CsOH} \cdot \mathrm{H}_{2} \mathrm{O}$ activated by complexing agent $(\mathrm{L}) ;\left[\mathrm{CsOH} \cdot \mathrm{H}_{2} \mathrm{O}\right]_{\mathrm{O}}=[\mathrm{L}]_{\mathrm{o}}=0.1 \mathrm{~mol} /$ $\mathrm{dm}^{3}$

\begin{tabular}{lllllll}
\hline $\mathrm{No}$ & Initiating system & {$[\text { Monomer }]_{\mathrm{o}}\left(\mathrm{mol} / \mathrm{dm}^{3}\right)$} & Time $(\mathrm{h})$ & Yield $(\%)$ & $M_{\mathrm{n}}(\mathrm{SEC})$ & $M_{\mathrm{w}} / M_{\mathrm{n}}(\mathrm{SEC})$ \\
\hline 1 & $\mathrm{CsOH} \cdot \mathrm{H}_{2} \mathrm{O} / 18 \mathrm{C} 6$ & $\mathrm{PO}(2.0)$ & 170 & 99 & 2000 & 1.29 \\
2 & $\mathrm{CsOH} \cdot \mathrm{H}_{2} \mathrm{O} / 18 \mathrm{C} 6$ & $\mathrm{PO}(5.0)$ & 390 & 99 & 5100 & 1.20 \\
3 & $\mathrm{CsOH} \cdot \mathrm{H}_{2} \mathrm{O} / \mathrm{C} 222$ & $\mathrm{PO}(2.0)$ & 140 & 99 & 1800 & 1.22 \\
4 & $\mathrm{CsOH} \cdot \mathrm{H}_{2} \mathrm{O} / \mathrm{C} 222$ & $\mathrm{PO}(5.0)$ & 350 & 98 & 4900 & 1.17 \\
5 & $\mathrm{CsOH} \cdot \mathrm{H}_{2} \mathrm{O} / 18 \mathrm{C} 6$ & $\mathrm{BO}(2.0)$ & 250 & 97 & 2700 & 1.25 \\
6 & $\mathrm{CsOH} \cdot \mathrm{H}_{2} \mathrm{O} / 18 \mathrm{C} 6$ & $\mathrm{BO}(5.0)$ & 460 & 98 & 4200 & 1.19 \\
7 & $\mathrm{CsOH} \cdot \mathrm{H}_{2} \mathrm{O} / \mathrm{C} 222$ & $\mathrm{BO}(2.0)$ & 220 & 97 & 2500 & 1.20 \\
8 & $\mathrm{CsOH} \cdot \mathrm{H}_{2} \mathrm{O} / \mathrm{C} 222$ & $\mathrm{BO}(5.0)$ & 415 & 99 & 4000 & 1.26 \\
9 & $\mathrm{CsOH} \cdot \mathrm{H}_{2} \mathrm{O} / 18 \mathrm{C} 6$ & $\mathrm{SO}(2.0)$ & 490 & 99 & 3000 & 1.28 \\
10 & $\mathrm{CsOH} \cdot \mathrm{H}_{2} \mathrm{O} / 18 \mathrm{C} 6$ & $\mathrm{SO}(5.0)$ & 610 & 98 & 4600 & 1.30 \\
11 & $\mathrm{CsOH} \cdot \mathrm{H}_{2} \mathrm{O} / \mathrm{C} 222$ & $\mathrm{SO}(2.0)$ & 460 & 99 & 2700 & 1.24 \\
12 & $\mathrm{CsOH} \cdot \mathrm{H}_{2} \mathrm{O} / \mathrm{C} 222$ & $\mathrm{SO}(5.0)$ & 595 & 97 & 4000 & 1.33 \\
\hline
\end{tabular}


Table 2 Characterization of polyether-diols obtained in the polymerization of glycidyl ethers initiated with $\mathrm{CsOH} \cdot \mathrm{H}_{2} \mathrm{O}$ activated by complexing agent $(\mathrm{L}) ;\left[\mathrm{CsOH} \cdot \mathrm{H}_{2} \mathrm{O}\right]_{\mathrm{O}}=[\mathrm{L}]_{\mathrm{o}}=0.1 \mathrm{~mol} / \mathrm{dm}^{3}$

\begin{tabular}{|c|c|c|c|c|c|c|}
\hline No & Initiating system & {$[\text { Monomer }]_{\mathrm{o}}\left(\mathrm{mol} / \mathrm{dm}^{3}\right)$} & Time (h) & Yield $(\%)$ & $M_{\mathrm{n}}(\mathrm{SEC})$ & $\begin{array}{l}M_{\mathrm{w}} / M_{\mathrm{n}} \\
(\mathrm{SEC})\end{array}$ \\
\hline 13 & $\mathrm{CsOH} \cdot \mathrm{H}_{2} \mathrm{O} / 18 \mathrm{C} 6$ & PGE (2.0) & 130 & 99 & 2700 & 1.27 \\
\hline 14 & $\mathrm{CsOH} \cdot \mathrm{H}_{2} \mathrm{O} / 18 \mathrm{C} 6$ & PGE (5.0) & 270 & $\begin{array}{l}\text { (a) } 60 \\
\text { (b) } 40\end{array}$ & $\begin{array}{l}6400 \\
600\end{array}$ & $\begin{array}{l}1.23 \\
1.29\end{array}$ \\
\hline 15 & $\mathrm{CsOH} \cdot \mathrm{H}_{2} \mathrm{O} / \mathrm{C} 222$ & PGE (2.0) & 115 & 99 & 2500 & 1.21 \\
\hline 16 & $\mathrm{CsOH} \cdot \mathrm{H}_{2} \mathrm{O} / \mathrm{C} 222$ & PGE(5.0) & 250 & 98 & 5000 & 1.29 \\
\hline 17 & $\mathrm{CsOH} \cdot \mathrm{H}_{2} \mathrm{O} / 18 \mathrm{C} 6$ & IPGE (2.0) & 110 & $\begin{array}{l}\text { (a) } 24 \\
\text { (b) } 50 \\
\text { (c) } 26\end{array}$ & $\begin{array}{l}5400 \\
2500 \\
800\end{array}$ & $\begin{array}{l}1.03 \\
1.10 \\
1.11\end{array}$ \\
\hline 18 & $\mathrm{CsOH} \cdot \mathrm{H}_{2} \mathrm{O} / 18 \mathrm{C} 6$ & IPGE (5.0) & 245 & $\begin{array}{l}\text { (a) } 57 \\
\text { (b) } 43\end{array}$ & $\begin{array}{l}5200 \\
2400\end{array}$ & $\begin{array}{l}1.04 \\
1.12\end{array}$ \\
\hline 19 & $\mathrm{CsOH} \cdot \mathrm{H}_{2} \mathrm{O} / \mathrm{C} 222$ & IPGE (2.0) & 100 & $\begin{array}{l}\text { (a) } 75 \\
\text { (b) } 25\end{array}$ & $\begin{array}{l}4700 \\
2100\end{array}$ & $\begin{array}{l}1.03 \\
1.09\end{array}$ \\
\hline 20 & $\mathrm{CsOH} \cdot \mathrm{H}_{2} \mathrm{O} / \mathrm{C} 222$ & IPGE (5.0) & 230 & $\begin{array}{l}\text { (a) } 60 \\
\text { (b) } 40\end{array}$ & $\begin{array}{l}4800 \\
2300\end{array}$ & $\begin{array}{l}1.08 \\
1.17\end{array}$ \\
\hline 21 & $\mathrm{CsOH} \cdot \mathrm{H}_{2} \mathrm{O} / 18 \mathrm{C} 6$ & AGE (2.0) & 105 & $\begin{array}{l}\text { (a) } 70 \\
\text { (b) } 30\end{array}$ & $\begin{array}{l}5300 \\
2400\end{array}$ & $\begin{array}{l}1.04 \\
1.15\end{array}$ \\
\hline 22 & $\mathrm{CsOH} \cdot \mathrm{H}_{2} \mathrm{O} / 18 \mathrm{C} 6$ & AGE (5.0) & 225 & $\begin{array}{l}\text { (a) } 65 \\
\text { (b) } 35\end{array}$ & $\begin{array}{l}5200 \\
2600\end{array}$ & $\begin{array}{l}1.07 \\
1.14\end{array}$ \\
\hline 23 & $\mathrm{CsOH} \cdot \mathrm{H}_{2} \mathrm{O} / \mathrm{C} 222$ & $\operatorname{AGE}(2.0)$ & 95 & $\begin{array}{l}\text { (a)20 } \\
\text { (b)57 } \\
\text { (c) } 23\end{array}$ & $\begin{array}{l}5300 \\
2400 \\
600\end{array}$ & $\begin{array}{l}1.02 \\
1.08 \\
1.09\end{array}$ \\
\hline 24 & $\mathrm{CsOH} \cdot \mathrm{H}_{2} \mathrm{O} / \mathrm{C} 222$ & $\operatorname{AGE}(5.0)$ & 215 & $\begin{array}{l}\text { (a) } 7 \\
\text { (b) } 13 \\
\text { (c) } 42 \\
\text { (d) } 30 \\
\text { (e) } 5 \\
\text { (f) } 3\end{array}$ & $\begin{array}{l}18,000 \\
10,500 \\
5000 \\
2300 \\
750 \\
450\end{array}$ & $\begin{array}{l}1.01 \\
1.03 \\
1.05 \\
1.09 \\
1.03 \\
1.02\end{array}$ \\
\hline
\end{tabular}

Molar masses ( $M_{\mathrm{n}}$ ) of PPO-diols (1-4), PBO-diols (5-8), PSO-diols (9-12) and their dispersities $\left(M_{\mathrm{w}} / M_{\mathrm{n}}\right)$ are collected in Table 1 .

It was suggested, that initiation occurs exclusively in liquid phase, i.e., it is mediated by the part of initiator, which is soluble in the reaction mixture. It causes increase of $M_{\mathrm{n}}$. Polarity of the medium depends on the kind and initial concentration of the monomer, which also influences $M_{\mathrm{n}}$ of polymers. Moreover, chain transfer to water results in decrease of $M_{\mathrm{n}}$. Polymers synthesized in the presence of $\mathrm{C} 222$ has a little lower $M_{\mathrm{n}}$ than obtained with $18 \mathrm{C} 6$ at the same monomer concentration. It may result from slight increase in initiator concentration in the reaction mixture containing C222 ligand. Relatively high dispersity of the polymers obtained ( $M_{\mathrm{w}} / M_{\mathrm{n}}=1.17-1.34$ ) results from chain transfer reaction to water and slow solubilization of initiator during the polymerization. It was established, that PPO-diols and PSO-diols obtained in this work do not contain macromolecules with unsaturated starting groups. Signals in unsaturated region, 

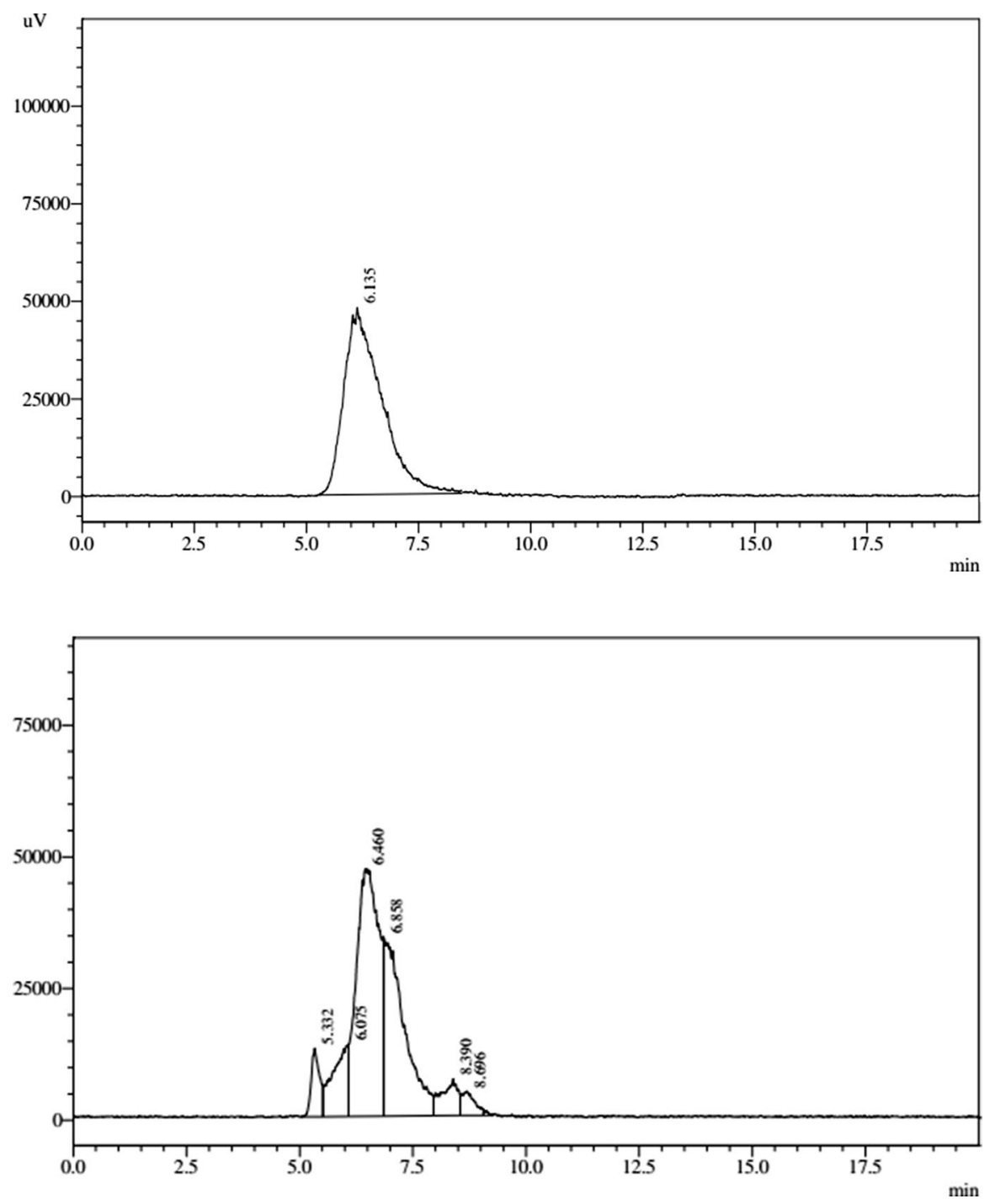

Fig. 1 Modality of polyether-diols prepared by anionic ring opening polymerization of glycidyl ethers initiated with $\mathrm{CsOH} \cdot \mathrm{H}_{2} \mathrm{O}$ activated by complexing agent; (1) PPGE-diol (16); (2) PAGE-diol (24)

i.e., at 116.7 and $134.9 \mathrm{ppm}$ for PPO-diols as well at 133.2 and $159.7 \mathrm{ppm}$ for PSO-diols were not observed in ${ }^{13} \mathrm{C}$ NMR spectrum. FTIR analysis of PPOs and PSOs did not indicate signals of $\mathrm{C}=\mathrm{C}$ bonds in their spectra neither at 1600-1680 $\left(\mathrm{C}=\mathrm{C}\right.$ bond stretching) or at $3300-3200 \mathrm{~cm}^{-1}$ (sp2 $\mathrm{C}-\mathrm{H}$ bond stretching). However, such signals were detected in other systems with $\mathrm{K}^{+}$counterion $[8,26,27]$. It indicates, that the presence of $\mathrm{Cs}^{+}$ions and high amount of water completely 
eliminate unsaturation in these polymers, due to chain transfer reaction to water. In the studied systems, the rate of this reaction is evidently much more higher, than the rate of chain transfer to monomer.

Polyether-diols (1-12) are unimodal. Unexpectedly, polymers synthesized from glycidyl ethers are, in general, bimodal (13-24) (Table 2). One of them, i.e., (24) consists even six fractions.

It is worth noting, that dispersities of fractions (a) are lower than (b). Dispersities of some fraction are extremely low (1.01-1.05). Figure 1 shows SEC chromatograms of two exemplary polyether-diols.

$M_{\mathrm{n}}$ of main fraction (a) of PIPGE-diol (18) obtained at $[M]_{\mathrm{o}}=2.0 \mathrm{~mol} / \mathrm{dm}^{3}$ is about two-fold higher than $M_{\mathrm{n}}$ of fraction (b). Similar effect is observed for PIPGE (20) prepared at $\left[M_{\mathrm{o}}\right]=5.0 \mathrm{~mol} / \mathrm{dm}^{3}$. Unexpectedly, $M_{\mathrm{n}}$ of fractions do not increase at much higher initial concentration of monomer. In the presence of C222, molar masses are lower. Similar phenomenon occurs in the case of PAGE-diols. The same heterogenicity and dissolving of the initiator with the course of polymerization may be responsible for the not observed increase of $M_{\mathrm{n}}$ of the product with increasing concentration of monomer (more initiator in the ionic form-smaller $M_{\mathrm{n}}$ ).

MALDI-TOF spectrum of polymer (24) (Fig. 2) reveals one series of signals at $m / z$ 954.2-6775.3. These signals represent macromolecules which consist central oxygen atom and two terminal hydroxyl groups. For example, peaks at $m / z$ 1981.7, 3808.7 and 4379.0 belong to macromolecules possessing 17, 33 and 38 monomer units $\left(M_{\text {calc }}=1981.4,3809.1\right.$ and 4378.6, respectively). These macromolecules form adducts with sodium ions.

Basing on the results obtained, the course of polymerization is proposed in Scheme 5 .

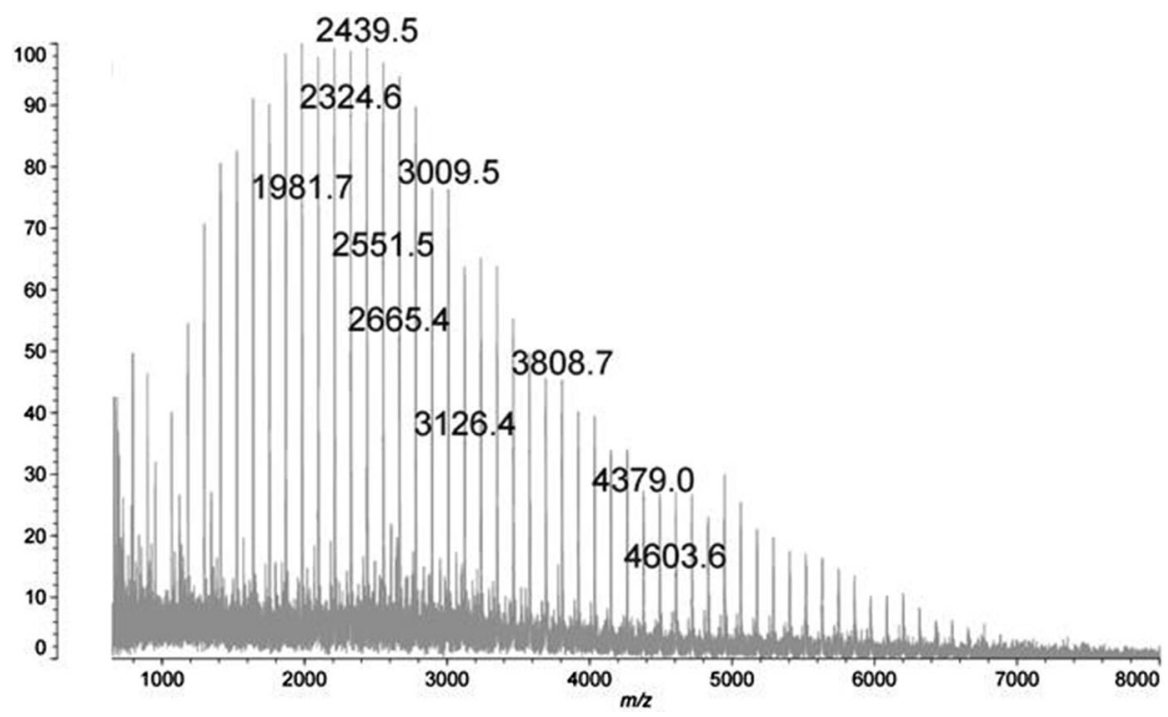

Fig. 2 MALDI-TOF spectrum of PAGE-diol (24) prepared by use of $\mathrm{CsOH} \cdot \mathrm{H}_{2} \mathrm{O}$ activated by C222 
Formation of two or more fraction in the polymerization of some oxiranes needs some comments. It is generally accepted, that in the polymerization process bimodality exclusively appears, when there are two species, propagating with different rate constants and that these species do not exchange fast enough [28]. According to this statement, it was proposed, that in the studied systems various kinds of anionic centers with different reactivity in growing polymer chains should be formed and be responsible for polymodality of some polymers (Scheme 6).

On the other hand, the heterogenicity of the system (transfer of an initiator from solid state to liquid followed by its ionization) may be consider as a reason of polymodality. However, unimodality observed in some polyethers indicates, that formation of two or more fractions in other polymers depends also on the kind of monomer. Explanation of this phenomenon needs further investigations.
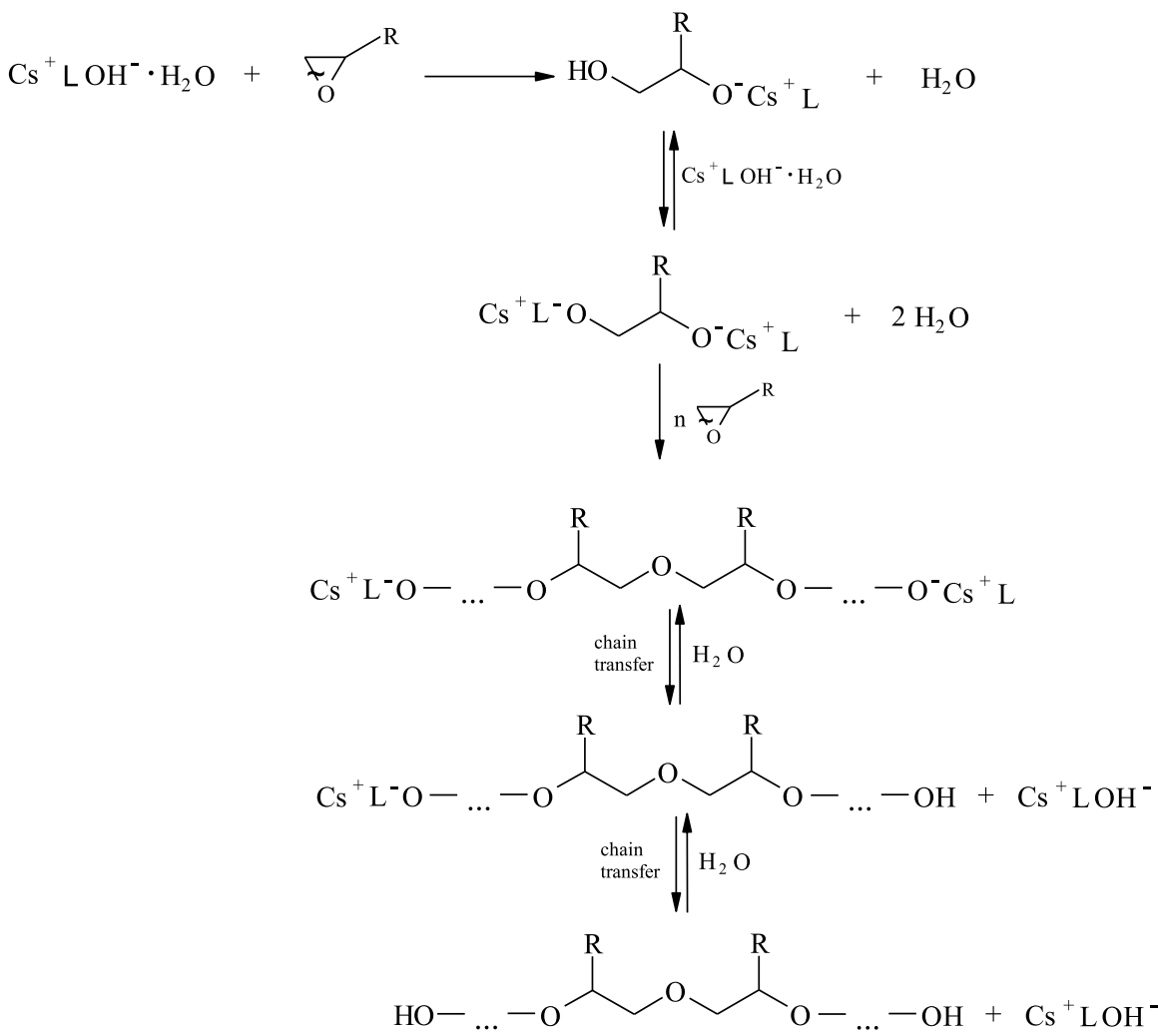

Scheme 5 Polymerization of monosubstituted oxiranes in the presence of $\mathrm{CsOH} \cdot \mathrm{H}_{2} \mathrm{O}$ activated by complexing agent $(\mathrm{L})$ 


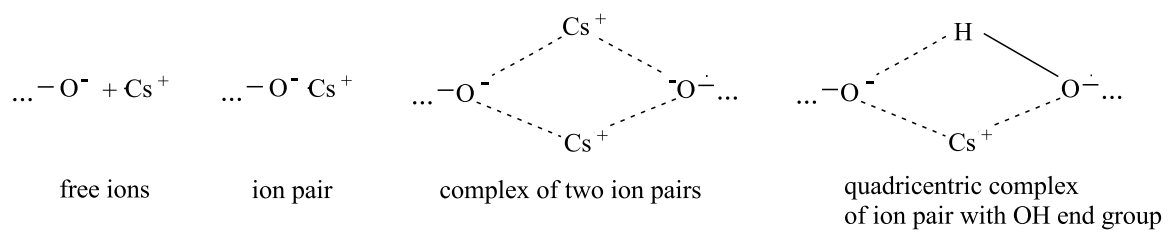

Scheme 6 Various reactive species formed in anionic polymerization of monosubstituted oxiranes initiated with $\mathrm{CsOH} \cdot \mathrm{H}_{2} \mathrm{O}$ (ligand was omitted)

\section{Conclusions}

Cesium hydroxide monohydrate $\left(\mathrm{CsOH} \cdot \mathrm{H}_{2} \mathrm{O}\right)$ was applied as initiator for heterogeneous polymerization of monosubstituted oxiranes in THF at room temperature. Several systems were activated by macrocyclic ligands complexing metal cation, i.e., 18C6 or C222. Main features of prepared polyether-diols are:

- PPO-diols, PBO-diols, PSO-diols and some PPGE-diols are unimodal; $M_{\mathrm{n}}$ of these polymers are 2000-5100, whereas dispersities are relatively high $\left(M_{\mathrm{w}} /\right.$ $\left.M_{\mathrm{n}}=1.17-1.33\right)$;

- PPO-diols and PSO-diols are free of unsaturated monools;

- PAGE-diols and PIPGE-diols are in general, bimodal; $M_{\mathrm{n}}$ of the fractions practically do not depend on initial monomer concentration, and their dispersities are relatively low $\left(M_{\mathrm{w}} / M_{\mathrm{n}}=1.03-1.29\right)$;

- Bimodality of some polymers can be explained by the formation of two species propagating with different rate constants, which do not exchange quickly enough;

- Some of prepared polyether diols could be useful for fabrication of new polyurethane elastomers due to their relatively high $M_{\mathrm{n}}$, low dispersity, and lack of unsaturation.

\section{Compliance with ethical standards}

Conflict of interest The authors declare that they have no conflict of interest.

Open Access This article is licensed under a Creative Commons Attribution 4.0 International License, which permits use, sharing, adaptation, distribution and reproduction in any medium or format, as long as you give appropriate credit to the original author(s) and the source, provide a link to the Creative Commons licence, and indicate if changes were made. The images or other third party material in this article are included in the article's Creative Commons licence, unless indicated otherwise in a credit line to the material. If material is not included in the article's Creative Commons licence and your intended use is not permitted by statutory regulation or exceeds the permitted use, you will need to obtain permission directly from the copyright holder. To view a copy of this licence, visit http://creativecommons.org/licen ses/by/4.0/. 


\section{References}

1. Zhang ZQ, Xu GY, Wang F, Dong SL, Li Y (2004) Characterization and demulsification of poly(ethylene oxide)-block-poly(propylene oxide)-block-poly(ethylene oxide) copolymers. J Colloid Interface Sci 277:464-470. https://doi.org/10.1016/j.jcis.2004.04.035

2. Gosa KI, Uricanu V (2002) Emulsions stabilized with PEO-PPO-PEO block copolymers and silica. Colloids Surf A 197:257-269. https://doi.org/10.1016/S0927-7757(01)00902-5

3. Izukawa T, Kunihiro T, (1999) Nishikawa A (Eds.), M.C.I. US Patent 5,916,994

4. Jeong B, Bae YH, Lee DS, Kim SW (1997) Biodegradable block copolymers as injectable drugdelivery systems. Nature 388:860-862. https://doi.org/10.1038/42218

5. Mathur AM, Drescher B, Scranton AB, Klier J (1998) Polymeric emulsifiers based on reversible formation of hydrophobic units. Nature 392:367-370. https://doi.org/10.1038/32856

6. Ionescu M (2008) Chemistry and technology of polyols for polyurethanes. Rapra Technology Limited, Shropshire

7. Steiner EC, Pelletier RR, Trucks RO (1964) A Study of the Polymerization of Propylene Oxide Catalyzed by Anhydrous Potassium Hydroxide. J Am Chem Soc 86:4678-4686. https://doi. org/10.1021/ja01075a031

8. Grobelny Z, Matlengiewicz M, Jurek J, Michalak M, Kwapulińska D, Swinarew A, Schab-Balcerzak E (2013) The influence of macrocyclic ligands and water on propylene oxide polymerization initiated with anhydrous potassium hydroxide in tetrahydrofuran. Eur Polymer J 49:32773288. https://doi.org/10.1016/j.eurpolymj.2013.06.035

9. Becker H, Wagner G (1984) Zur Übertragungsreaktion bei der anionichen Polymerisation von Oxiranen VI. Zum Einfluß von Kronenetherzusätzen auf die Polymerisation von Propylenoxid. Acta Polym 35:28-32. https://doi.org/10.1002/actp.1984.010350106

10. Becker H, Wagner G, Stolarzewicz A (1982) Zur Übertragungsreaktion bei der anionischen Polymerisation von Oxiranen. III. Zur Dynamik der Doppelbindungsbildung bei der Propylenoxidpolymerisation. Acta Polym 33:34-37. https://doi.org/10.1002/actp.1982.010330107

11. Yu GE, Heatley F, Booth C, Blease TG (1994) Anionic polymerization of propylene oxide: isomerization of allyl ether to propenyl ether end groups. J Polym Sci Part A Polym Chem 32:1131-1135. https://doi.org/10.1002/pola.1994.080320615

12. Ding J, Price C, Booth C (1991) Use of crown ether in the anionic polymerization of propylene oxide-1 Rate of polymerization. Eur Polym J 27:891-894. https://doi.org/10.1016/00143057(91)90028-M

13. Ding J, Heatley F, Price C, Booth C (1991) Use of crown ether in the anionic polymerization of propylene oxide-2. Molecular weight and molecular weight distribution. Eur Polymer J 27:895899. https://doi.org/10.1016/0014-3057(91)90029-N

14. Grobelny Z, Swinarew A, Jurek-Suliga J, Skrzeczyna K, Gabor J, Łężniak M (2016) The influence of crown ether and alcohol on unsaturation and molar mass of poly(propylene oxide)s prepared by use of potassium $t$-butoxide: reinvestigation of chain transfer reactions. Int $\mathbf{J}$ Anal Chem. https://doi.org/10.1155/2016/3727062

15. Grobelny Z, Matlengiewicz M, Jurek-Suliga J, Golba S, Skrzeczyna K (2018) The influence of initiator and macrocyclic ligand on unsaturation and molar mass of poly(propylene oxide)s prepared with various anionic system. Polym Bull 75:1101-1112. https://doi.org/10.1007/s0028 9-017-2078-z/

16. Wegener G, Brandt M, Duda L, Hofmann J, Klesczewski B, Koch D, Kumpf R-J, Orzesek H, Pirkl H-G, Six Ch, Steinlein Ch, Weisbech M (2001) Trends in industrial catalysis in the polyurethane industry. Appl Catal A 221:303-335. https://doi.org/10.1016/S0926-860X(01)00910-3

17. PierrePrice LEStChC (1956) The room temperature polymerization of propylene oxide. J Am Chem Soc 78:3432-3436. https://doi.org/10.1021/ja01595a047

18. Snyder Jr W.H., Ph. D. Thesis, University of Pennsylvania, 1961

19. Freidly HR (1992) Reaction Polymers. In: WF Gum, W Riese, H Ulrich (Eds), Hanser Publishers: NY p. 66

20. Curtis CJ, Levis Jr WW, Pizzini LC inventors, BASF Wyandotte Corporation, assignee US Patent 4,487,853, 1984

21. Exner JH, Steiner EC (1974) Solvation and ion pairing of alkali-metal alkoxides in dimethyl sulfoxide. J Am Chem Soc 96:1782-1787. https://doi.org/10.1021/ja00813a022 
22. Dimitrov P, Rangelov S, Dworak A, Tsvetanov ChB (2004) Synthesis and associating properties of poly(ethoxyethylglycidyl ether)/poly(propylene oxide) triblock copolymers. Macromolecules 37:1000-1008. https://doi.org/10.1021/ma0354039

23. Siggia S (1963) Quantitative organic analysis via functional groups. Wiley, USA, p 241

24. Lamb JD, Izatt RM, Christensen JJ, Eatough DJ (1979) Coordination chemistry of macrocyclic compounds. In: Melson GA (Ed.), Plenum Press, New York, p. 145-218

25. Issa D, Ellaboudy A, Janakiraman R, Dye JL (1984) Magnetic-susceptibilities and electron-paramagnetic resonance-spectra of a ceside and an electride. J Phys Chem 88:3847-3851. https://doi. org/10.1021/j150661a032

26. Kauffmann E, Dye JL, Lehn JM, Popov AI (1980) A study of the inclusive and exclusive cesium cryptates in nonaqueous solvents by cesium-133 NMR. J Am Chem Soc 102:2274-2278. https:// doi.org/10.1021/ja00527a023

27. Grobelny Z, Matlengiewicz M, Jurek-Suliga J, Golba S, Skrzeczyna K, Kwapulińska D (2017) Ring opening polymerization of styrene oxide initiated with potassium alkoxides and hydroxyalkoxides activated by 18-crown-6: determination of mechanism and preparation of new polyether-polyols. Polym Bull 74:4763-4780. https://doi.org/10.1007/s00289-017-1976-4/

28. Penczek S, Cypryk M, Duda A, Kubisa P, Słomkowski S (2007) Living ring-opening polymerizations of heterocyclic monomers. Prog Polym Sci 32:247-282. https://doi.org/10.1016/j.progpolyms ci.2007.01.002

Publisher's Note Springer Nature remains neutral with regard to jurisdictional claims in published maps and institutional affiliations.

\section{Affiliations}

\section{Zbigniew Grobelny $^{1}\left[\right.$ [ - Justyna Jurek-Suliga ${ }^{2}$. Sylwia Golba ${ }^{2}$}

Zbigniew Grobelny

zbigniew.grobelny@us.edu.pl

1 Institute of Chemistry, University of Silesia, 40-007 Katowice, Poland

2 Institute of Materials Science, University of Silesia, 40-007 Katowice, Poland 